UDK 656.7:614.4

347.824:614.4

Preliminary communication

\title{
AIR TRANSPORT AND PASSENGER RIGHTS PROTECTION DURING AND AFTER THE CORONAVIRUS (COVID-19) PANDEMIC*
}

\author{
Aleksandra Vasilj, PhD, Full Professor \\ Faculty of Law Osijek, Josip Juraj Strossmayer University of Osijek \\ Stjepana Radića 13, Osijek, Croatia \\ avasilj@pravos.hr
}

\section{Biljana Činčurak Erceg PhD, Assistant Professor}

Faculty of Law Osijek, Josip Juraj Strossmayer University of Osijek

Stjepana Radića 13, Osijek, Croatia

biljana.cincurak@pravos.hr

\author{
Aleksandra Perković, bacc. admin. publ., Head of Cabin Crew \\ Croatia Airlines, Croatian Air Transport Company Ltd. \\ Bani 75B, Buzin, Croatia \\ aleksandra.perkovic@croatiaairlines.hr
}

\begin{abstract}
A pandemic caused by the COVID-19 has caused disorders and enormous damage in all modes of transport. Carriers as well as transport users have faced great challenges of maintaining traffic. Measures and requirements imposed on them were often obscure, imprecise, and the journey itself was uncertain. Passengers were in fear of whether they would be able to reach their destination, but also whether they will succeed in preserving their health. Carriers, on the other hand, have also sought to adapt and provide passengers with safe transport. Nevertheless, the pandemic caused financial collapse of many carriers, landed the world fleet and closed many airports.

Various legal instruments related to the protection of public health are applied in air transport, and they have been adopted within the framework of the World Health Organisation (WHO), the International Civil Aviation Organisation (ICAO) and the European Aviation Safety Agency (EASA), which will be presented in the paper.
\end{abstract}

This paper is a product of work that has been fully supported by the Faculty of Law Osijek, Josip Juraj Strossmayer University of Osijek, under the project No. IP-PRAVOS-5 "Challenges and threats of modern transport and new legal solutions". 
Various epidemiological measures related to the COVID-19 coronavirus pandemic have been prescribed in air transport, applicable during the journey, which have certain specifics in relation to other modes of transport. The paper will present epidemiological measures as well as the procedure applied when there is a passenger on the flight who shows symptoms of an infectious disease, and new procedures related to transport of goods. It will also address the obligation to complete certain forms and provide various information as well as the obligation to compensate costs for cancelled flights.

There is no doubt that the COVID-19 pandemic has a significant economic impact on air transport, and efforts will be made to present measures and provide forecasts for the recovery of air traffic in the period that follows. The paper will also address the question as to whether existing legislation and measures are appropriate, whether relevant international organisations have taken prompt measures to protect and ensure air transport during the pandemic, and whether sufficient measures have been taken to protect the health of passengers on the flight.

Keywords: air transport, COVID-19 pandemic, passenger rights, epidemiological measures, bealth safety

\section{INTRODUCTION}

Air transport is one of the most COVID-19 pandemic affected transport modes. World media reported on cancelled flights, closed airports, fleet landing and the complete airline collapse. According to available data, the decline in air transport in 2020 amounted to more than $60 \%{ }^{1}$ compared to 2019 , and such data is also applicable to the Republic of Croatia, i.e. $60 \% .^{2}$

In order to prevent the spread of SARS-Cov-2, flights were cancelled and states made various decisions and adopted numerous measures. The cancelled flights had a detrimental effect not only on the transport of passengers but also on the transport of cargo, and problems also arose with the transport of essential medical supplies. All this required urgent measures at European Union level, but also globally, with international organisations such as the World Health Organisation (hereinafter: WHO) and the International Civil Aviation Organisation (hereinafter: ICAO) that played an important role. WHO, ICAO and the European Aviation Safety Agency (hereinafter: EASA) have issued a series of health and safety guidance documents for airlines, crew members, and airports, aimed at preventing coronavirus infection and spread. However, all stakeholders are faced with a difficult task - to ensure a normal course of flights in 'abnormal' conditions.

1 ICAO, Effects of Novel Coronavirus (COVID-19) on Civil Aviation: Economic Impact Analysis, [https:// www.icao.int/sustainability/Documents/COVID-19/ICAO_Coronavirus_Econ_Impact.pdf], Accessed 28 March 2021.

2 Hrvatska kontrola zračne plovidbe, Financijski plan HKZP-a za 2021., [https://www.crocontrol.hr/ app/uploads/2021/02/HKZP-FIN-PLN-2021.pdf], Accessed 28 March 2021, p. 5. 
We have been witnessing the difficult flow of traffic, especially passenger traffic, and a large number of dissatisfied passengers, especially on international flights. Uncertainty as to whether and under what conditions it will be possible to reach the destination while maintaining good health has resulted in numerous travel postponements.

The paper presents various legal instruments related to the protection of public health that are applied in air transport, which are adopted within the framework of WHO, ICAO and EASA. Various epidemiological measures related to the COVID-19 coronavirus pandemic that have been prescribed in air transport will also be presented. The paper will also address the obligation to complete certain forms and provide various information as well as the obligation to compensate costs for cancelled flights.

There is no doubt that the COVID-19 virus pandemic has had a significant economic impact on air transport, and efforts will be made to present measures and provide forecasts for the recovery of air traffic in the period that follows. Finally, the authors will try to answer the question as to whether existing legislation and measures are appropriate.

\section{AIR TRANSPORT AND PUBLIC HEALTH PROTECTION}

\subsection{A historical overview of the development of the infectious disease protection and control system}

Infectious diseases have taken many lives throughout history. The need for international cooperation in the field of health care resulted in the organisation of the first International Sanitary Conference in Paris in 1851, which aimed to harmonise the implementation of mandatory quarantine measures in maritime transport in Europe. ${ }^{3}$ After the cholera epidemic of 1892, the first International Sanitary Convention on the systematic infectious disease control and prevention was adopted. Conferences in Dresden in 1893 and Paris in 1894 resulted in two additional conventions relating to cholera, while the conference in Venice in 1897 resulted in an international convention dealing with prevention of the spread of plague. These four conventions were consolidated into a single International Sanitary Convention in $1903,{ }^{4}$ which was changed again at the conference held in Paris in $1912 .{ }^{5}$

World Health Organisation, Global Health Histories, Origin and development of health cooperation, [https://www.who.int/global_health_histories/background/en/], Accessed 21 January 2021.

Ibid.

Stock, P. G., The International Sanitary Convention of 1944, Proceedings of the Royal Society of Medicine, Vol. XXXVIII, Issue 7, 1945, p. 310. 
The idea of forming a permanent body to manage this system was developed in this period. Thus, in Europe, the Office International d'Hygiène Publique was established in 1909, which managed the infectious disease control and prevention system until the beginning of World War I, while in America, there was the International Sanitary Bureau, which was later renamed the Pan American Sanitary Bureau. $^{6}$

In the period between World War I and World War II, there were various changes in the institutions themselves, but it can generally be considered that the joint initiative in the field of infectious disease prevention in that period was in the background. In 1943, the United Nations Relief and Rehabilitation Administration (UNRRA) ${ }^{7}$ was established in Washington D.C. as an institution whose task was, inter alia, to monitor and prevent infectious diseases, and the Health Committee was established as an advisory body. The European Regional UNRRA Office was set up in London. This institution ceased to function in 1946 with the initiative to establish a special organisation within the United Nations. Based on this initiative, the World Health Organisation (WHO) was founded in 1948 as a specialised agency of the United Nations. Its main purpose is to achieve the highest possible level of health for all peoples, and the health of all peoples has been established as a prerequisite for achieving international peace and security. ${ }^{8}$

\subsection{Infectious diseases and air transport}

The increase in air transport in the early 1930s allows for increasing connectivity between different countries, but also raises the question of an increased risk of the spread of infectious diseases. In order to create common procedures and measures for the prevention of infection among both passengers and crew members, the International Sanitary Convention for Aerial Navigation ${ }^{9}$ was adopted in 1933. This convention, although not widely accepted, represents a turning point in air

See also: International Sanitary Convention, League of Nations Treaty Series - LNTS, Vol. 4, No. 112, 1912. p. 28. The International Sanitary Convention of 1912 was amended in 1926, 1933, 1938 and 1944.

6 World Health Organisation, op. cit., note 3.

7 Stock, P. G., The International Sanitary Convention of 1944, Proceedings of the Royal Society of Medicine, Vol. XXXVIII, Issue 7, 1945, pp. 309-316.

8 For more details, see: Lapaš, D., Pravo mecunarodnih organizacija, Narodne novine, Zagreb, 2008, p. 204.

$9 \quad$ Stock, op. cit., note 5, p. 311.

This convention was later amended in 1944 . The Republic of Croatia is not a party to the Convention. United Nations Treaty Series Online, International Sanitary Convention for Aerial Navigation, 1944, [https://treaties.un.org/Pages/showDetails.aspx?objid=080000028016391a\&clang=_en], Accessed 20 March 2021. 
transport in terms of international cooperation in the field of the prevention and control of infectious diseases. The document contains binding procedures for five infectious diseases, i.e. plague, cholera, yellow fever, typhus and smallpox. Also, the obligation to fill in the Personal Declaration of Origin and Health document has been introduced, which the commander of an arriving aircraft must present to the health officer together with all necessary certificates of additional hygiene measures. ${ }^{10}$

At the time when the UNRRA was established, an initiative was launched in Washington D.C., the United States, to create common international civil air traffic regulation and coordination. Under this initiative, the Convention on International Civil Aviation ${ }^{11}$ (also known as the Chicago Convention) was signed in Chicago in 1944 and it entered into force in 1947. The Chicago Convention established the International Civil Aviation Organisation (ICAO) as a specialised organisation whose task is to coordinate the establishment of various new rules, standards and procedures necessary to conduct international air transport. ICAO works to develop international Standards and Recommended Practices (SARPs) used by states when enacting national civil aviation regulations. ${ }^{12}$ In 1947, ICAO became a specialised agency of the United Nations. ${ }^{13}$

In its Article 14, the Convention on International Civil Aviation provides for measures to prevent the spread of infectious diseases (cholera, typhus (epidemic), smallpox, yellow fever, plague, and other diseases) by air and obliges Contracting States to cooperate with organisations dealing with international regulations on sanitary measures applicable to aircraft in terms of the implementation of measures to combat infectious diseases and prevent their spread. ${ }^{14}$

In 1951, WHO issued the International Sanitary Regulations, a document that regulates the prevention and control of specific infectious diseases. In 1969, this document was revised and renamed the International Health Regulations (IHR) and is legally binding upon the signatories. Over time, the IHR have undergone revisions, primarily to regulate procedures for infectious diseases not listed in the

10 Stock, op. cit., note 5, p. 311.

11 Convention on International Civil Aviation, Official Gazette, International Agreements, No. 1/1996.

12 Vasilj, A.; Činčurak Erceg, B., Prometno pravo i osiguranje, Sveučilište Josipa Jurja Strossmayera u Osijeku, Pravni fakultet Osijek, Osijek, 2016, p. 49.

13 ICAO, ICAO and the United Nations, [https://www.icao.int/about-icao/History/Pages/icao-and-theunited-nations.aspx], Accessed 21 January 2021.

14 Convention on International Civil Aviation [https://www.icao.int/publications/Documents/7300_ cons.pdf], Accessed 30 January 2021. 
document, and a particularly significant revision of $2005^{15}$ followed the outbreak of the Severe Acute Respiratory Syndrome (SARS). As it is necessary to prescribe guidelines and procedures related to air transport, as two specialised UN agencies, ICAO and WHO work closely together, and following the amendment to the International Health Regulations in 2005, ICAO revised the Standards and Recommended Practices (SARPs). ${ }^{16}$

The SARPs represent the standards embedded by virtue of the annexes in the Chicago Convention under Article 37. ${ }^{17}$ Annex 9 to the Chicago Convention (2005) imposes an obligation on all operators to report any suspected case of infectious disease on aircraft and to comply with all the provisions of the Convention related to infectious diseases. ${ }^{18}$

In the same year, in cooperation with WHO, the International Air Transport Association (IATA) and the Airports Council International (ACI), ICAO published Guidelines for states concerning the management of communicable disease posing a serious public health risk. ${ }^{19}$ Based on the new guidelines, the parties to the Chicago Convention are required to develop their national aviation safety plans $s^{20}$ and procedures related to the protection and prevention of infectious diseases, and these guidelines were issued to assist in the development of these plans.

15 International Health Regulations (2005) (Odluka o objavi Međunarodnih zdravstvenih propisa (2005)), Official Gazette, International Agreements, No. 9/2013.

16 ICAO, Managing Communicable Disease in Aviation, [https://www.icao.int/safety/aviation-medicine/ pages/healthrisks.aspx], Accessed 30 January 2021.

17 Pursuant to Article 37(1) of the Chicago Convention, all Contracting States undertake to cooperate to ensure uniformity in regulations, standards, procedures, and organisation relating to aircraft, personnel, airways and auxiliary services in all areas where such uniformity would facilitate and improve air navigation.

All Contracting States to the Chicago Convention undertake to accept all prescribed standards, which enables unified procedures and gives the right to overfly another country's airspace.

18 ICAO, International Standards and Recommended Practices, Annex 9 to the Convention on International Civil Aviation, [https://www.ifrc.org/docs/IDRL/Chicago\%20Convention\%20Annex\%209.pdf], Accessed 3 February 2021.

At the same time, Member States undertake to take all necessary measures to prevent the spread of infectious diseases such as cholera, typhus, smallpox, yellow fever, plague and other infectious diseases, as assessed at a specific moment by the Member State.

19 ICAO, Guidelines for states concerning the management of communicable disease posing a serious public health risk [https://www.icao.int/safety/aviation-medicine/guidelines/avinfluenza_guidelines.pdf], Accessed 3 February 2021.

20 The 2015 National Aviation Safety Programme is in force in the Republic of Croatia, and the Safety Plan is defined in Annex 4 to the aforementioned National Programme. (Decision on the adoption of the National Aviation Safety Programme (Odluka o donošenju Nacionalnog programa sigurnosti u zračnom prometu), Official Gazette, No. 141/2015). 
In 2006, the Collaborative Arrangement for the Prevention and Management of Public Health Events in Civil Aviation (CAPSCA) ${ }^{21}$ was concluded. With this agreement, in addition to $\mathrm{WHO}, \mathrm{ICAO}$ calls for various international, national and local organisations to prepare joint plans and programmes aimed at the protection of public health in the field of air transport. ${ }^{22}$ The three most important areas covered by this programme relate to:

1. Population - implementation of a measure to control the risk of a pandemic;

2. Passengers and aircraft crew - measures to reduce the risk of the spread of infectious diseases on board the aircraft;

3. Economic measures - the prevention of a financial impact on air transport due to a pandemic. ${ }^{23}$

CAPSCA also provides assistance in relation to the implementation of ICAO Standards and Regulations (SARPs) and International Health Regulations (IHR), assesses readiness of states to respond to events in air transport that pose a risk to public health, and supports and assists the states in developing their national aviation safety programmes in the field of public health protection. ${ }^{24}$

The revised Annex 9, which has been in force since 2007, has introduced changes and regulatory obligations related to airlines, flight and cabin crew, the procedure to be carried out in case there is a suspected case of infectious disease on board the aircraft, aircraft cleaning and disinfection, biohazardous waste disposal and the like. In cooperation with WHO and IATA, the Passenger Locator Card (PLC) form was introduced. The PLC is intended for rapid data collection for the purpose of providing the information needed by public health authorities. A Health Declaration has been added to the existing General Declaration form, which lists the infectious disease symptoms as guidelines for assessment and where data will be entered subsequently on passengers who develop such symptoms on board the aircraft, as well as the circumstances that may have led to the spread of the disease and information on disinfection done. The pilot-in-command is obliged to inform air traffic control (ATC) on the presence of symptoms of an infectious disease on board the aircraft. The list of symptoms has been agreed upon and ac-

21 ICAO, Collaborative Arrangement for the Prevention and Management of Public Health Events in Civil Aviation - CAPSCA, [https://www.icao.int/safety/CAPSCA/Pages/About-CAPSCA.aspx], Accessed 6 February 2021.

22 Ibid.

23 Evans A., ICAO and prevention of spread of disease, [https://www.icao.int/SAM/Documents/2009/ MEDSEM/AVMED-\%20prevention\%20of\%20spread\%20of\%20disease.pdf], Accessed 6 February 2021.

24 ICAO, op. cit., note 21 . 
cepted by all public health and aviation organisations: fever $\left(38^{\circ} \mathrm{C}\right.$ or greater $)+$ one of the following: "appearing obviously unwell; persistent coughing; impaired breathing; persistent diarrhoea; persistent vomiting; skin rash; bruising or bleeding without previous injury; or, confusion of recent onset". ${ }^{25}$

Annex 6 of 2009 introduced additional standards (SARPs) providing for the quantities of necessary on-board medical supplies and equipment and the introduction of the Universal Precaution Kit (UPK) "for the use of cabin crew members in managing incidents of ill health associated with a case of suspected communicable disease, or in the case of illness involving contact with body fluids" ${ }^{26}$

We will also mention here Suspected Communicable Disease Guidelines for cabin crew, i.e. guidelines for procedures of cabin crew in the event of a case of suspected communicable disease on board an aircraft, published in 2017 by IATA in cooperation with $\mathrm{WHO}$ and ICAO. ${ }^{27}$

Let us just mention that at European Union level, the European Union Aviation Safety Agency (EASA) has been operating since 2002, working closely with ICAO and supporting the implementation of common standards in Member States. ${ }^{28}$ EASA also cooperates with IATA, in particular in the field of security and other areas of common interest.

\section{COVID-19 PANDEMIC AND AIR TRANSPORT}

On 31 December 2019, in the city of Wuhan, Hubei province in China, several cases of non-specific pneumonia were reported, ${ }^{29}$ for which the causal agent, a novel coronavirus (later named SARS-Cov-2) was identified in January 2020, and a new disease caused by this virus is called coronavirus disease COVID-19. ${ }^{30} \mathrm{At}$ the meeting of the Emergency Committee convened by WHO on 30 January

25 ICAO, ICAO health-related documents, p. 6 [https://www.icao.int/MID/Documents/2013/capsca-mid3/ICAOHealthRelatedSARPsandguidelines.pdf], Accessed 7 February 2021.

26 Ibid., p. 2.

27 IATA, Suspected Communicable Disease, Guidelines for cabin crew, [https://www.iata.org/contentassets/f1163430bba94512a583eb6d6b24aa56/health-guidelines-cabin-crew.pdf], Accessed 7 February 2021.

28 EASA, Cooperation with the International Civil Aviation Organisation (ICAO), [https://www.easa.europa.eu/domains/international-cooperation/cooperation-with-ICAO], Accessed 7 February 2021.

29 Croatian National Institute of Public Health, Epidemija pneumonijelakutne respiratorne bolesti uzrokovane novim koronavirusom, Kina, [https://www.hzjz.hr/sluzba-epidemiologija-zarazne-bolesti/epidemija-pneumonije-povezana-s-novim-koronavirusom-kina/], Accessed 7 February 2021.

30 Croatian National Institute of Public Health, Pitanja i odgovori o bolesti uzrokovanom novim koronavirusom COVID-19, [https://www.hzjz.hr/sluzba-epidemiologija-zarazne-bolesti/pitanja-i-odgovori-o-novom-koronavirusu-2019-ncov/], Accessed 7 February 2021. 
2020, it was decided to declare this disease a Public Health Emergency of International Concern - PHEIC, ${ }^{31}$ and on 11 March 2020, WHO declared COVID-19 a pandemic. ${ }^{32}$

The deteriorating epidemiological situation around the world has significantly affected air transport, especially because of fear of increased risk and SARS-CoV-2 transmission due to large passenger flow, and time spent at an airport and on the aircraft. Air transport has faced new circumstances and the need for effective measures in unforeseen situations. Measures to prevent the spread of the epidemic prescribed and implemented by states pursuant to their national regulations, together with regulations and standards by WHO, ICAO, IATA, FAA, EASA and other partners, were aimed at reducing the possibility of disease transmission, providing passenger and staff protection and restoring passenger confidence in air travel, which will consequently affect the recovery of air transport as the industry most affected by the economic consequences of the pandemic.

Given the rapid spread of the virus and the danger of in-flight COVID-19 transmission, on 6 March 2020, ICAO and WHO published a Joint statement ${ }^{33}$ containing aviation-related instructions placing emphasis on the importance of complying with prescribed standards (SARPs) relating to preventive measures for infectious diseases. At the same time, ICAO has taken a leading role in providing guidance and information to CAPSCA Member States and organisations, and together with IATA, the Airports Council International (ACI) and other partners, it has joined forces to develop joint measures and procedures to "provide guidance to aviation authorities, airlines and airports, on appropriate measures aimed to protect the health of the travelling public and reduce the risk of transmission." ${ }^{34}$

Based on the ICAO guidelines, EASA and the United States Federal Aviation Administration in collaboration with IATA published guidelines with COVID-19 prevention and control procedures for aircraft operators and personnel, and various procedures to enable safe air travel. Due to a need to deliver medical supplies

31 Croatian National Institute of Public Health, op. cit., note 29.

32 WHO, WHO Director-General's opening remarks at the media briefing on COVID-19- 11 March 2020, [https://www.who.int/director-general/speeches/detail/who-director-general-s-opening-remarks-atthe-media-briefing-on-covid-19---11-march-2020], Accessed 7 February 2021.

33 ICAO, ICAO and WHO Joint Statement on COVID-19, [https://www.icao.int/Security/COVID-19/ PublishingImages/Pages/Statements/Joint\%20ICAO-WHO\%20Statement\%20on\%20COVID-19. pdf], Accessed 7 February 2021.

34 ICAO, ICAO-WHO publish joint statement on COVID-19, [https://www.icao.int/Newsroom/Pages/ ICAO-WHO-publish-joint-statement-on-COVID-19.aspx], Accessed 8 February 2021. 
and other important goods, EASA has issued a temporary permit for transport of cargo in the passenger cabin. ${ }^{35}$

\subsection{COVID-19 Aviation Health Safety Protocol and other procedures and measures}

At EU level, the European Commission, in cooperation with the European Council, has issued the European Roadmap towards lifting COVID-19 containment measures ${ }^{36}$ containing recommendations to Member States in terms of the preservation of public health. ${ }^{37}$ Based on this document, EASA, in cooperation with the European Centre for Disease Prevention and Control (hereinafter: ECDC), has issued the COVID-19 Aviation Health Safety Protocol - Operational guidelines for the management of air passengers and aviation personnel in relation to COVID-19 pandemic (hereinafter: the COVID-19 Aviation Health Safety Protocol), ${ }^{38}$ a document that provides guidelines and is a source of best practice for all air transport stakeholders with the aim of protecting public health and preventing the spread of SARS-Cov-2. It is based on the Plan-Do-Check-Act (PDCA) principle aimed at protecting air passengers and aviation personnel, and providing confidence in air travel. Measures and restrictions contained therein are the result of the current situation and their lifting depends on regular assessment of the situation and the current pandemic phase.

The COVID-19 Aviation Health Safety Protocol can generally be divided into two thematic units:

1. management of passengers, and

2. management of aviation personnel.

35 EASA, Airworthiness aspects for transport of cargo in the passenger cabin of Large Aeroplanes, [https:// www.easa.europa.eu/newsroom-and-events/news/airworthiness-aspects-transport-cargo-passenger-cabin-large-aeroplanes], Accessed 10 February 2021. See also: EASA (European Union Aviation Safety Agency), Guidelines transport of cargo in passenger compartment - exemptions under article 71(1) of Regulation 2018/1139 (The Basic Regulation), [https:/www.easa.europa.eu/sites/default/files/dfu/ Guidelines $\% 20$ for $\% 20$ the $\% 20$ transport $\% 20$ of $\% 20$ cargo $\% 20$ in $\% 20$ passenger\%20aircraft_EASA_issue3_final.pdf], Accessed 10 February 2021.

36 Joint European Roadmap towards lifting COVID-19 containment measures [2020] OJ C 126/01.

37 European Commission, A European roadmap to lifting coronavirus containment measures, [https://ec.europa.eu/info/live-work-travel-eu/coronavirus-response/european-roadmap-lifting-coronavirus-containment-measures_en], Accessed 11 February 2021.

38 EASA and ECDC, COVID-19 Aviation Health Safety Protocol Operational guidelines for the management of air passengers and aviation personnel in relation to the COVID-19 pandemic, Issue No. 02, Issue date: 30 June 2020, [https://www.easa.europa.eu/sites/default/files/dfu/EASA-ECDC_ COVID-19_Operational\%20guidelines $\% 20$ for $\% 20$ management $\% 20$ of $\% 20$ passengers_v2.pdf], Accessed 11 February 2021. 


\subsubsection{Management of passengers}

Since transport has been associated with health risks related to COVID-19, Gutiérrez, Miravet and Domènech rightly state that "public transport operators must minimise the risk of contagion both on-board and during passenger waiting time."39

Management of air passengers provides for guidelines and measures for passengers before their trip, i.e. before arriving at the airport, those implemented at the airport and protective measures implemented on board the aircraft. Although these measures were aimed at restoring passenger confidence in air travel, a large number of guidelines combined with an uneven approach depending on national regulations leads to confusion and resistance of passengers to comply with what has been prescribed.

Aircraft operators and airport operators are obliged to inform passengers of the travel restrictions referring to those passengers who may have COVID-19-compatible symptoms, or of a travel ban imposed on a passenger diagnosed with elevated skin temperature at the airport where such thermal screening is conducted. Then, before the journey, all passengers must be informed that they are obliged to wear face masks and mouth-nose covers, with the exemption of children under 6 years of age and persons who cannot wear a face mask due to medical reasons, and reminded that the physical distance must be maintained. ${ }^{40}$

The COVID-19 Aviation Health Safety Protocol provides for guidelines in such cases and passengers who do not comply with the prescribed measures shall be denied entry to the airport and the aircraft. Also, if a passenger refuses to comply with the prescribed protection measures in-flight, crew members shall apply the procedures related to handling cases of unruly or disruptive passengers. ${ }^{41}$

Although the COVID-19 Aviation Health Safety Protocol provides for the possibility of an exemption to wearing a face mask or a face covering, ${ }^{42}$ it does not specify how this shall be implemented. Due to situations when passengers may refuse to wear a protective mask on a flight for a medical reason, airline operators have started to request passengers exempt from wearing face masks to present medical certificates. ${ }^{43}$

39 Gutiérrez, A.; Miravet, D.; Domènech, A., COVID-19 and urban public transport services: emerging challenges and research agenda, Cities \& Health, 2020, p. 1.

40 EASA and ECDC, op. cit., note 38.

41 Ibid. p. 9.

$42 \quad$ Ibid. p. 7.

43 Lufthansa, Medical certificate: Wearing of a medical protective mask, [https://www.lufthansa.com/content/dam/lh/documents/book-and-manage/travel-information/we-care/faq-mouth-nose-cover/certifi- 
On board an aircraft or while purchasing an airline ticket, passengers are required to fill in a Passenger Locator form ${ }^{44}$ and a Passenger Health Declaration. Based on these forms, passenger health status data is collected, i.e. data on possible exposure to COVID-19 and the appearance of symptoms, as well as passenger data used by public health authorities for contact tracing purposes. ${ }^{45}$

A Passenger Health Declaration is a statement passengers are required to have on air travel along with other documents for verification purposes during travel and on arrival. A passenger must present this declaration when boarding the aircraft, or when asked to do so by airport staff or by the designated airport medical authority. ${ }^{46}$

It is important that the symptoms listed on the Health Declaration form are identical to the symptoms of other diseases that are not contraindications to air travel. Given that not all airports and airlines have an elaborate procedure and rapid tests, the question arises as to whether denied travel in the event of symptoms is justified or not.

Pursuant to Article 6 of Council Directive 2004/82/EC of 29 April 2004 on the obligation of carriers to communicate passenger data, airlines are obliged to collect passenger related data when they purchase a ticket or enter a check-in process that is to be communicated by the airlines to law enforcement and immigration authorities. ${ }^{47}$ These data are also used for preventing the spread of infectious diseases in accordance with the Schengen Borders Code. ${ }^{48}$

Given that the data obtained are not sufficient to monitor passenger contacts in the case of a COVID-19 pandemic and their retrieval from the database is a slow process, ECDC has prescribed the minimum data necessary for the tracing process to be effective:

cate-mask-exemption-20210125-en.pdf], Accessed 12 February 2021.

44 EASA and ECDC, op. cit., note 38, pp. 21-22; ICAO, Public Health Passenger Locator Form, [https:// www.icao.int/safety/aviation-medicine/guidelines/AvInfluenza_guidelines_app.pdf], ], Accessed 12 February 2021.

45 EASA and ECDC, op. cit., note 38, p. 31.

46 European Centre for Disease Prevention and Control, Considerations relating to passenger locator data, entry and exit screening and health declarations in the context of COVID-19 in the EU/EEA and the UK, [https://www.ecdc.europa.eu/sites/default/files/documents/ECDC-one-page_EntryScreening_Passenger-Locator-and-Health-Declarations.pdf], Accessed 12 February 2021.

47 Council Directive 2004/82/EC of 29 April 2004 on the obligation of carriers to communicate passenger data [2004] OJ L 261/24.

48 Regulation (EU) 2016/399 of the European Parliament and of the Council of 9 March 2016 on a Union Code on the rules governing the movement of persons across borders (Schengen Borders Code) [2016] OJ L 77/1. 
- Flight number and seat number,

- Full name,

- Date of birth (optional, but may be useful to differentiate between people with common names),

- Telephone number: a functional mobile,

- Email address. ${ }^{49}$

A passenger locator card contains all this information and passengers are required to fill out this form before or during their flight. The PLC data collection and processing method depends on national regulations, which creates additional pressure on both air passengers and aviation personnel. Another challenge in this data collection is the implementation of Regulation (EU) 2016/679 of the European Parliament and of the Council on the protection of natural persons with regard to the processing of personal data and on the free movement of such data (General Data Protection Regulation - GDPR). ${ }^{50}$ Airlines are expected to collect and submit these forms to public health authorities and it is up to the Member States "to assess whether the transfer of passenger location data from airlines to public health authorities complies with the requirements under the General Data Protection Legislation (GDPR), taking into account the legal requirements under their national law." ${ }^{1}$

Unlike other means of public transport, physical distancing is not mandatory in air transport, because it has been proved that the possibility of in-flight infectious disease transmission is extremely small, and the use of personal protective equipment reduces this risk even further. For this reason, airlines will ensure a physical distance between passengers if it is operationally feasible, and when it is allowed by passenger load, cabin configuration, and aircraft mass and balance requirements..$^{52}$ If it is not possible to maintain the distance between passengers, airlines are obliged to prescribe and apply risk-mitigation measures. One such measure relates to cabin air recirculation and the use of high-efficiency particulate air (HEPA) filters that do not let SARS-CoV-2. According to the IATA website, "The risk of transmission in the modern cabin environment is low for a number

\footnotetext{
49 ECDC, op. cit., note 46, p. 3.

50 Regulation (EU) 2016/679 of the European Parliament and of the Council of 27 April 2016 on the protection of natural persons with regard to the processing of personal data and on the free movement of such data, and repealing Directive 95/46/EC (General Data Protection Regulation) [2016] OJ L $119 / 1$.

51 ECDC, op. cit., note 46, p. 3.

52 EASA and ECDC, op. cit., note 38, p. 30.
} 
of reasons: passengers face the same direction, seatbacks act as barriers, air flow is from the top to bottom, and the air is also very clean." ${ }^{3}$

In addition to the above measures, IATA proposes additional measures for the safety of air passengers:

- "Temperature screening of passengers, airport workers and travellers,

- Boarding and deplaning processes that reduce contact with other passengers or crew,

- Limiting movement within the cabin during flight,

- More frequent and deeper cabin cleaning, and

- Simplified catering procedures that lower crew movement and interaction with passengers." 54

Aircraft and airport premises need to be additionally disinfected. ECDC has published guidelines ${ }^{55}$ regarding cleaning and disinfection of the premises. These guidelines also apply to airport premises, and are contained in the guidelines published by EASA in the document Guidance on Aircraft Cleaning and Disinfection in relation to the COVID-19 pandemic. ${ }^{56}$

\subsubsection{Management of aviation personnel}

Management of aviation personnel focuses on personnel protection measures aimed at reducing the risk of infectious disease transmission between passengers and aviation personnel. The procedures related to physical distancing, hand hygiene and respiratory etiquette are identical to those prescribed for passengers. The aircraft operator is obliged to have a crew health monitoring programme, and aircrew members and airport staff are exempt from airport screening procedures. ${ }^{57}$

53 IATA, Cabin Air Quality [https://www.iata.org/en/youandiata/travelers/health/cabin-air/], Accessed 12 February 2021.

54 IATA, LATA Calls for Passenger Face Covering and Crew Masks, [https://www.iata.org/en/pressroom/ pr/2020-05-05-01/], Accessed 12 February 2021.

55 European Centre for Disease Prevention and Control, Disinfection of environments in healthcare and non-healthcare settings potentially contaminated with SARS-CoV-2, [https://www.ecdc.europa. eu/en/publications-data/disinfection-environments-covid-19], [https://www.ecdc.europa.eu/sites/ default/files/documents/Environmental-persistence-of-SARS_CoV_2-virus-Options-for-cleaning2020-03-26_0.pdf], Accessed 12 February 2021.

56 EASA, Guidance on Aircraft Cleaning and Disinfection in relation to the COVID-19 pandemic, [https:// www.easa.europa.eu/sites/default/files/dfu/EASA\%20Guidance\%20on\%20aircraft\%20cleaning\%20 and\%20disinfection-issue\%202.pdf], Accessed 12 February 2021.

57 EASA and ECDC, op. cit., note 38, p. 24. 
EASA has published Guidance Management of Crew Members in relation to the COVID-19 pandemic. ${ }^{58}$ According to these guidelines, when creating the crew schedule, aircraft operators should maintain the same teams in order to avoid cross-contamination. ${ }^{59}$ This document also prescribes health self-monitoring procedures and the procedure when an in-flight passenger or crew member shows symptoms that are compatible with COVID-19.

Given the large number of procedures that differed from regulators and operators, and with the aim of enforcing the prescribed standards in a quality manner, IATA has published the Health Safety Checklist for Airline Operators. ${ }^{60}$ This document is used as a list of procedures by operators when conducting self-assessment or as a list of guidelines by those operators that want to structure their health operations management in this way.

\subsection{Cargo in the passenger cabin}

A large number of aircraft have been grounded and the number of cargo flights has decreased since the emergence of the SARS-CoV-2 virus as about $40 \%$ of annual global air cargo is typically transported in the bellyhold of passenger aircraft. ${ }^{61}$ There are a number of problems that arise in freight transport including various regulations that are dynamic and unharmonised regarding testing and quarantine. A serious problem was a 14-day quarantine at the destination not only for the entire crew, but also for cargo, which implied 14-day delay. Due to this unacceptable situation, "airlines are lobbying for governments to respond with practical exemptions to these regulations such as exempting flight crew who do not interact with public from the quarantine regulations." 62

At the same time, due to the reduced number of flights, the delivery of humanitarian aid and medical supplies has become a challenge for airlines. Due to the need to transport this type of cargo, airlines have started to consider the possibility of transporting cargo in the passenger cabin. Since passenger cabins are not designed

58 EASA, Guidance on the management of crew members in relation to the COVID-19 pandemic, [https:// www.easa.europa.eu/sites/default/files/dfu/EASA-COVID-19_Guidance\%20on\%20Management\%20of\%20Crew\%20Members_issue\%202.pdf], Accessed 14 February 2021.

59 Ibid., p. 7.

60 IATA, IATA Health Safety Standards Checklist for Airline Operators, [https://www.icao.int/safety/CAPSCA/PublishingImages/Pages/Coronavirus/IATA\%20Health\%20Safety\%20Standards\%20Checklist $\% 20$ for\%20Airline\%20Operators.pdf], Accessed 15 February 2021.

${ }_{61}$ World Economic Forum, Coronavirus and aviation: Why is air cargo grounded when the world needs it most?, [https://www.weforum.org/agenda/2020/04/coronavirus-aviation-why-is-air-cargo-groundedwhen-the-world-needs-it-most/], Accessed 15 February 2021.

62

Ibid. 
for the transport of cargo, it was necessary to prescribe the conditions under which such transport is possible.

ICAO has produced general guidelines related to aircraft modifications and the transport of dangerous goods $s^{63}$ in accordance with Annex 18 stipulating standards for the Safe Transport of Dangerous Goods by Air. ${ }^{64}$ The potential risks of such operations are the risk of smoke/fire in the passenger compartment as well as the risk of unlabelled or not correctly labelled dangerous goods.

IATA has issued Guidance for the transport of cargo and mail on aircraft configured for the carriage of passengers ${ }^{65}$ with detailed instructions for airlines and a prescribed risk assessment procedure: "Before considering such operation, a comprehensive safety risk assessment shall be performed involving all the relevant operational departments (i.e. ground, cargo, cabin, flight, engineering)." 66 Air transport regulations and aircraft manufacturers approve the transport of cargo in the passenger cabin, and in the case of special types of goods, operators must obtain approval from the regulator. The transport of dangerous goods in the passenger cabin is not allowed.

Based on an initiative by IATA and support from ICAO, EASA has issued Guidelines for the Transport of Cargo in Passenger Compartment ${ }^{67}$, as a special exemption in terms of Regulation (EU) 2018/1139 of the European Parliament and of the Council, pursuant to which operators are required to request time-limited airworthiness approval for an aircraft whose configuration does not meet the clas-

63 See ICAO, Airworthiness of Aircraft, Repurposing aircraft passenger cabin for transport of cargo, [https:// www.icao.int/safety/COVID-19OPS/Pages/Airworthiness.aspx]; ICAO, Safety transport of COVID-19 vaccines on commercial aircraft, [https://www.icao.int/safety/OPS/OPS-Normal/Pages/Safety-transport-vaccines.aspx]; ICAO, Addendum No. 1 to the Technical Instructions for the safe transport of dangerous goods by air (2021/2022 Edition), [https://www.icao.int/safety/DangerousGoods/AddendumCorrigendum $\% 20$ to\%20the\%20Technical\%20Instructions/Doc\%209284-2021-2022.AddendumNo1.en.pdf]; ICAO, Addendum No. 2 to the Technical Instructions Instructions for the safe transport of dangerous goods by air (2021/2022 Edition) [https://www.icao.int/safety/DangerousGoods/AddendumCorrigendum $\% 20$ to\%20the\%20Technical\%20Instructions/Doc\%209284-2021-2022.AddendumNo2.en.pdf], Accessed 28 February 2021.

64 ICAO, Technical Instructions for the Safe Transport of Dangerous Goods by Air (Doc 9284), [https:// www.icao.int/safety/dangerousgoods/pages/technical-instructions.aspx], Accessed 21 February 2021.

65 IATA, Guidance for the transport of cargo and mail on aircraft configured for the carriage of passengers Ed 304 May 2020, [https://www.iata.org/contentassets/094560b4bd9844fda520e9058a0fbe2e/guidance-safe-transportation-cargo-passenger-cabin.pdf], Accessed 15 February 2021.

66 Ibid., p. 4.

67 EASA, European Union Aviation Safety Agency Guidelines Transport of Cargo in Passenger Compartment - Exemptions under Article 71(1) of Regulation (EU) 2018/1139 (The Basic Regulation), [https://www. easa.europa.eu/sites/default/files/dfu/Guidelines $\% 20$ for $\% 20$ the $\% 20$ transport $\% 20$ of $\% 20$ cargo $\% 20$ in\%20passenger\%20aircraft_EASA_Issue-5.pdf], Accessed 17 February 2021, p. 2. 
sifications prescribed for cargo transport. EASA has also prescribed what modifications in the passenger cabin must be made in order for the aircraft to receive such approval, and exceptionally, national regulators may also grant approval for aircraft that do not have the necessary modifications to enable the transportation of supplies essential for COVID-19 response. ${ }^{68}$ Soon, the American FAA also gave a one-year approval for the transport of goods in the passenger cabin. ${ }^{69}$

\section{THE ECONOMIC IMPACT OF THE PANDEMIC ON AIR TRANSPORT AND RELIEF MEASURES}

The crisis caused by the COVID-19 pandemic has had an unprecedented impact on air transport and the aviation industry. Since the beginning of international air transport, this is the biggest strategic challenge and disruption on a global scale.

As stated in the Covid-19 Guidelines for border management measures to protect health and ensure the availability of goods and essential services, the transport and mobility sector is essential to ensure economic continuity and "control measures should not undermine the continuity of economic activity and should preserve the operation of supply chains." ${ }^{70}$

At the beginning of the epidemic, when it was thought that the virus would remain only in China, the expected drop in revenue was 29.3 billion dollars. ${ }^{71}$ Given the rapid spread of the virus, according to IATA analyses, a loss in global passenger revenues of about USD 113 billion is estimated. ${ }^{72}$ The latest data shows that this amount could be much higher, i.e. that a decline in total revenue could amount to $44 \%$ of 2019 revenue, or USD 252 billion. $^{73}$

Although, globally speaking, air transport continues to function, major changes are visible: the number of flights has declined (see Figure 1), aircraft fleets have been grounded and thousands of employees have lost their jobs.

68 Ibid. See also Annex 1 of the Guidelines Transport of Cargo in Passenger Compartment.

69 FAA (U.S. Department of Transportation Federal Aviation Administration), Novel Coronavirus (COVID-19) Update, [https://www.faa.gov/news/updates/?newsId=94991], Accessed 17 February 2021.

70 European Commission, Covid-19 Guidelines for border management measures to protect health and ensure the availability of goods and essential services 2020/C 86 I/01 [2020] OJ C 861, p. 1.

71 IATA, IATA Updates COVID-19 Financial Impacts - Relief Measures Needed -, [https://www.iata. org/en/pressroom/pr/2020-03-05-01/], Accessed 20 February 2021.

72 Ibid.

73 Flight Safety Foundation, Pandemic, Non-medical operational safety aspects; Supplemental materials, [https://flightsafety.org/wp-content/uploads/2020/05/COVID-19-Roadmap-V2.pdf], Accessed 20 February 2021, p. 2. 


\section{Figure 1.}



Source: Ang, C., Visual Capitalist, One Year In: Air Travel Plummeted During the COVID-19 Pandemic, [https://www.visualcapitalist.com/air-travel-plummeted-during-covid-19-pandemic/], Accessed 22 March 2021.

The impact of the aviation industry on the global economy is extremely large. The 2019 Aviation Benefits Report said that this impact is approximately equivalent to the overall GDP of the United Kingdom. ${ }^{74}$ At European level, according to the 2016 results, that is $3.3 \%$ of all employment and $4.1 \%$ of all GDP in European countries. ${ }^{75}$

The data referring to the Republic of Croatia shows that after good results achieved in 2019, when air transport generated revenue of about HRK 4.9 billion, in 2020, due to the COVID-19 pandemic, according to the Air Transport Association of

74 Industry High Level Group (IHLG), Aviation Benefits Report 2019, [https://www.icao.int/sustainability/Documents/AVIATION-BENEFITS-2019-web.pdf], Accessed 20 February 2021, p. 17.

75 Air Transport Action Group (ATAG), Aviation benefits beyond borders, [https://aviationbenefits.org/ media/166711/abbb18_full-report_web.pdf], Accessed 20 February 2021, p. 44. 
the Croatian Chamber of Commerce, it recorded a decline of as much as $90 \%{ }^{76}$, or according to Croatia Control Ltd. (the Croatian air navigation service provider), a $60 \%$ fall. ${ }^{77}$

Aviation affects all branches of the economy, especially tourism, because it directly provides significant revenue for all stakeholders involved in the chain, such as travel agencies, hotels, restaurants, etc., and the economic impact on air transport will affect both tourism and the global economy. According to estimates that include the best outcome, in terms of revenue and operations, air transport is expected to return to 2019 levels in 2024 at the earliest, ${ }^{78}$ and states must give their support for the aviation industry in the form of clear and consistent measures to enable it to survive and to make passengers regain confidence and feel safe.

IATA highlights four key segments where government assistance is needed:

1. Extending the waiver from the 80-20 use-it-or-lose-it rule in the Worldwide Airport Slot Guidelines offering more flexibility to airline operators to plan schedules,

2. Continued financial assistance,

3. Extensions to wage subsidies and corporate taxation relief measures,

4. Avoiding increases in charges and fees. ${ }^{79}$

At EU level, one of the significant financial instruments is the Economic Stimulus Programme worth EUR 750 billion and offered by the European Central Bank to navigate the economic downturn across the eurozone. Also, EASA has adopted

76 Udruženje zračnog prometa HGK, Udruženje zračnog prometa: Nakon pada od 90\%, oporavak moguć tek 2024., [https://hgk.hr/odrzan-sastanak-udruzenja-zracnog-prometa], Accessed 20 February 2021.

77 Hrvatska kontrola zračne plovidbe, op. cit., note 2, p. 8.

78 Ibid.

EUROCONTROL has published three recovery scenarios to return to 2019 levels, which are related to the vaccination rate, as follows:

Scenario 1 - Vaccine made widely available for travellers (or end of pandemic) by Summer 2021 - by 2024.

Scenario 2 - Vaccine made widely available for travellers (or end of pandemic) by Summer 2022 - by 2026.

Scenario 3 - Vaccine not effective - returning to 2019 levels by 2029.

EUROCONTROL, EUROCONTROL Five-Year Forecast 2020-2024, Traffic not expected to reach 2019 levels until 2024 at earliest, [https://www.eurocontrol.int/publication/eurocontrol-five-year-forecast-2020-2024], Accessed 20 February 2021.

79 IATA, Continued Government Relief Measures Needed to get Airlines through the Winter, [https://www. iata.org/en/pressroom/pr/2020-06-16-01/], Accessed 20 February 2021. 
a number of regulations since the beginning of the pandemic, which enable safe operations in the time of the COVID crisis. ${ }^{80}$

\subsection{Air passenger rights and COVID-19}

It is well known that "a modern passenger requires punctuality, regularity, comfort, speed, economy, and above all safety while traveling." ${ }^{81}$ Developed passenger transport also includes issues referring to the protection of passenger rights. Passenger rights have gained importance in recent years, especially within the European Union, and ensuring a high level of protection of passenger rights is a significant part of transport policy.

Due to the large number of cancelled flights that generate high costs in terms of passenger compensation, and due to numerous rules and restrictions, and at the same time to protect passenger rights, the European Commission has published Interpretative Guidelines on EU passenger rights regulations in the context of the developing situation with Covid-19 ${ }^{82}$ (hereinafter: Interpretative Guidelines), which facilitate the interpretation and application of the protection of passenger rights during the COVID-19 pandemic. These Interpretative Guidelines also apply to Regulation (EC) No 261/2004 of the European Parliament and of the Council establishing common rules on compensation and assistance to passengers in the event of denied boarding and of cancellation or long delay of flights ${ }^{83}$.

Regulation (EC) No 261/2004 ${ }^{84}$ establishes minimum rights for passengers when: a) they are denied boarding against their will; b) their flight is cancelled; c) their

80 IATA, Relief measures, [https://www.iata.org/globalassets/iata/programs/covid/relief-measures-update. pdf], Accessed 20 February 2021.

81 Činčurak Erceg, B.; Vasilj, A.; Current Affairs in Passengers Rights Protection in the European Union, International Scientific Conference "EU Law in Context - Adjustment to Membership and Challenges of the Enlargement (ECLIC)“, Vol. 2 (2018), Osijek, p. 217.

82 Commission Notice Interpretative Guidelines on EU passenger rights regulations in the context of the developing situation with Covid-19 C/2020/1830, [2020] OJ C 89I/01.

83 Regulation (EC) No 261/2004 of the European Parliament and of the Council of 11 February 2004 establishing common rules on compensation and assistance to passengers in the event of denied boarding and of cancellation or long delay of flights, and repealing Regulation (EEC) No 295/91 [2004], OJ L 46/1.

${ }^{84}$ For more information about Regulation (EC) No 261/2004, its solutions, application and implementation problems, see: Fox, S. J.; Martin-Domingo, L., EU Air Passengers' Rights Past, Present, and Future: In an Uncertain World (Regulation (EC) 261/2004: Evaluation and Case Study), Journal of Air Law and Commerce Vol. 85, Issue 2, 2020; Drake, S., Delays, cancellations and compensation: Why are air passengers still finding it difficult to enforce their EU rights under Regulation 261/2004?, Maastricht Journal of European and Comparative Law, Vol. 27, No. 2, 2020, pp. 230-249.; Okeke, G.; Kokpan, B., Evaluation of the EU Regulation 261/2004 on Rights of Air Passengers in the Event of Delayed and Cancelled Flights, International Review of Law and Jurisprudence, Vol. 3, No. 2, 2021; 
flight is delayed (Article 1(1)). Specific provisions apply to passenger rights in the event of flight cancellation. According to Article 5 of Regulation (EC) No 261/2004, in case of flight cancellation, the passengers concerned shall have the right to: a) reimbursement or re-routing (Article 8), ${ }^{85}$ b) care (Article 9), and c) compensation (Article 7). As stated in the Interpretative Guidelines, given the unpredictability of the situation in the case of COVID-19, passengers cannot be provided with re-routing "at the earliest opportunity", as provided for in Article 8(1) (a) of Regulation (EC) No 261/2004, so in that case reimbursement of the ticket price or rerouting at a later stage might be preferable for the passenger. ${ }^{86} \mathrm{~A}$ large number of passengers cancelled their travel due to the pandemic, and in order to keep their passengers, the airlines offered a voucher with a new travel date. In contrast to this situation, if an airline cancels the flight and offers only a voucher, the passenger still has the right to choose between the voucher, reimbursement of the ticket price and re-routing. Under this provision, airlines generate high costs and in April 2020, twelve ${ }^{87}$ European countries asked the European Commission to "suspend the law requiring airlines to offer a full refund for cancelled flights

Steer; European Commission, Study on the current level of protection of air passenger rights in the EU, Final report, 2020, [https://op.europa.eu/en/publication-detail/-/publication/f03df002-335c-11eaba6e-01aa75ed71a1], Accessed 1 February 2021.; Činčurak Erceg, B.; Vasilj, A., Current Affairs in Passengers Rights Protection in the European Union, International Scientific Conference "EU Law in Context - Adjustment to Membership and Challenges of the Enlargement (ECLIC)“, Vol. 2 (2018), Osijek; Vasilj, A., Jačanje pravnog položaja putnika - potreba uskladivanja nacionalnih propisa s mectunarodnim konvencijama i propisima Europske unije, Pravni vjesnik, Vol. 27, No. 1, 2011; Radionov, N., Ćapeta, T., Marin. J., Bulum, B., Kumpan, A., Popović, N., Savić, I., Europsko prometno pravo, Zagreb, Sveučilište u Zagrebu, Pravni fakultet, 2011.; Proposal for a regulation of the European Parliament and of the council amending Regulation (EC) No 261/2004 establishing common rules on compensation and assistance to passengers in the event of denied boarding and of cancellation or long delay of flights and Regulation (EC) No 2027/97 on air carrier liability in respect of the carriage of passengers and their baggage by air, COM (2013) 130 final - 2013/0072 (COD); Commission Notice - Interpretative Guidelines on Regulation (EC) No 261/2004 of the European Parliament and of the Council establishing common rules on compensation and assistance to passengers in the event of denied boarding and of cancellation or long delay of flights and on Council Regulation (EC) No 2027/97 on air carrier liability in the event of accidents as amended by Regulation (EC) No 889/2002 of the European Parliament and of the Council [2016] OJ C 214.; Steer Davies Gleave, Exploratory study on the application and possible revision of Regulation 261/2004, Final report, 2012, [https://ec.europa.eu/transport/sites/ default/files/themes/passengers/studies/doc/2012-07-exploratory-study-on-the-application-and-possible-revision-of-regulation-261-2004.pdf], Accessed 1 February 2021.

85 According to Article 8, passengers are offered the choice between: a) reimbursement (refund); b) re-routing at the earliest opportunity, or c) re-routing at a later date at the passenger's convenience.

86 Commission Notice Interpretative Guidelines, op. cit., note 82, p. 2.

87 Belgium, Bulgaria, Cyprus, Czech Republic, France, Greece, Ireland, Latvia, Malta, the Netherlands, Poland and Portugal. Morgan, S., Twelve countries demand passenger rights suspension, [https://www. euractiv.com/section/aviation/news/twelve-countries-demand-passenger-rights-suspension/], Accessed 2 June 2021. 
and allow airlines to choose the means by which passengers are reimbursed" ${ }^{88}$ It is precisely for this reason that rules have been adopted at national level according to which airlines are allowed to offer passengers vouchers instead of refunds, such as the Italian "Cura Italia Decree", which allows that pursuant to the Guidelines: "such national measures do not fall under the scope of the EU passenger rights regulations. "89 Nevertheless, on 13 May 2020, the European Commission adopted Recommendation (EU) 2020/648 on vouchers offered to passengers and travellers as an alternative to reimbursement for cancelled package travel and transport services in the context of the COVID-19 pandemic, ${ }^{90}$ in which it emphasises that passengers have the choice between cash reimbursement and reimbursement in the form of a voucher. However, the Commission's main recommendation for airlines is to make vouchers more attractive, so that consumers will more easily accept them instead of the reimbursement.

Regulation (EC) No 261/2004 prescribes that under certain conditions passengers are also entitled to flight cancellation compensation; but, Article 5(3) also stipulates that "an operating air carrier shall not be obliged to pay compensation in accordance with Article 7 , if it can prove that the cancellation is caused by extraordinary circumstances which could not have been avoided even if all reasonable measures had been taken". However, Regulation (EC) No 261/2004 itself does not provide a definition of extraordinary circumstances. According to the aforementioned Interpretative Guidelines, the European Commission reckons that travel restrictions in the case of COVID-19 can be considered as such circumstances. ${ }^{91}$ As to the right to care, it still remains the obligation of the carrier. ${ }^{92}$

A large number of measures aimed at protecting public health have been adopted in the Member States at national levels, which restrict free movement and thus undermine the foundations of European integration. Measures aimed at restricting

${ }_{88}$ Lexology, Coronavirus and cancelled flights: refund or vouchers?, [https://www.lexology.com/library/detail.aspx?g=e82dc998-9496-4f35-8dd5-d8eeaae3b9da], Accessed 21 February 2021.

89 Commission Notice Interpretative Guidelines, op. cit., note 82, p. 3.

90 Commission Recommendation (EU) 2020/648 of 13 May 2020 on vouchers offered to passengers and travellers as an alternative to reimbursement for cancelled package travel and transport services in the context of the COVID-19 pandemic, C/2020/3125, [2020], OJ L 151/10.

91 It is also stated that "where the airline decides to cancel a flight and shows that this decision was justified on grounds of protecting the health of the crew, such cancellation should also be considered as "caused" by extraordinary circumstances." Commission Notice Interpretative Guidelines, op. cit., note 82 , p. 5.

92 The right to care according to Article 9 of Regulation (EC) No 261/2004 consists of meals and refreshments in a reasonable relation to the waiting time, hotel accommodation if necessary, and transport to the place of accommodation. 
the spread of the virus have affected passenger rights and their free movement. ${ }^{93}$ There was no coordinated approach at Member State level and the Council called on Member States to cooperate.

Since March 2020, the Commission and the Council have adopted guidelines and recommendations in response to the crisis. The Council issued Recommendation (EU) 2020/1475 on a coordinated approach to the restriction of free movement in response to the COVID-19 pandemic ${ }^{94}$ aimed at ensuring the coordination and timely communication at EU level of measures taken by Member States that restrict free movement due to the COVID-19 (coronavirus) pandemic. The Council Recommendation contains specific recommendations that should be adopted by Member States in order to limit restrictions on free movement to only what is strictly necessary to protect public health, given that a unilateral approach has a significant impact on the European economy. It is especially important to ensure uniform regulations for categories of persons travelling for business reasons.

In the Communication from the Commission on additional COVID-19 response measures ${ }^{95}$ the Commission concluded that "unilateral and uncoordinated action undermines the impact of the EU's response and the confidence of citizens," 96 and launched an initiative to create a joint response to the crisis with a set of new measures to be applied at EU level. One of the measures is to enable safe travel and free movement within the EU and the Schengen Area. Although the majority of states still prescribe certain restrictions,${ }^{97}$ according to this Communication, "such restrictions can be justified in the interests of public health, they must be proportionate and must not discriminate between citizens of different Member States." 98

93 E.g. "Pursuant to Council Regulation (EC) No. 1008/2008, on March 11, 2020, Spain announced flight suspensions of all direct flights between Italy and Spain, with the exception of stopovers for non-traffic purposes, state flights, cargo-only, humanitarian, medical, and urgency flights." Fox, S. J.; Martin-Domingo, L., EU Air Passengers' Rights Past, Present, and Future: In an Uncertain World (Regulation (EC) 261/2004: Evaluation and Case Study), Journal of Air Law and Commerce, Vol. 85, Issue 2, 2020, p. 300.

94 Council Recommendation (EU) 2020/1475 of 13 October 2020 on a coordinated approach to the restriction of free movement in response to the COVID-19 pandemic [2020] OJ L 337/3.

95 Communication from the Commission to the European Parliament, the European Council and the Council on additional COVID-19 response measures, [2020] COM/2020/687 final.

96 Ibid., p. 1.

${ }_{97}$ We witnessed that at the beginning of the pandemic many national governments and local authorities applied travel restrictions and reintroduced internal border controls inside the EU, with only essential travel permitted. Also, many Member States require persons from other Member States to undergo quarantine or a test before or upon entry into their territory, with requirements modelled according to the epidemiological situation.

$98 \quad$ Ibid., p. 8. 
In order to enable safe travel, a joint response of Member States is aimed at better passenger information, cooperation with ECDC, establishing passenger testing protocols, a consistent application of quarantine rules, establishing a digital European passenger locator form and launching a Re-open EU application that would provide rapid access to up-to-date information on measures implemented at national levels. ${ }^{99}$

In response to the transport situation, the European Union has adopted a number of documents. Since the analysis of other legislation would exceed the scope of this paper, we note that the following documents have been adopted in the European Union: Commission Delegated Regulation (EU) 2020/2115 of 16 December 2020 amending Regulation (EC) No 1008/2008 of the European Parliament and of the Council as regards the temporary extension of exceptional measures to address the consequences of the COVID-19 pandemic with regard to operating licences, ${ }^{100}$ Regulation (EU) 2020/459 of the European Parliament and of the Council of 30 March 2020 amending Council Regulation (EEC) No 95/93 on common rules for the allocation of slots at Community airports, ${ }^{101}$ European Commission, Covid-19 Guidelines for border management measures to protect health and ensure the availability of goods and essential services, ${ }^{102}$ Consolidated text: Council Recommendation (EU) 2020/1475 of 13 October 2020 on a coordinated approach to the restriction of free movement in response to the COVID-19 pandemic, Communication from the Commission Guidelines concerning the exercise of the free movement of workers during COVID-19 outbreak, Communication from the Commission European Commission Guidelines: Facilitating Air Cargo Operations during COVID-19 outbreak [2020], OJ C 100I, Communication from the Commission Guidelines concerning the exercise of the free movement of workers during COVID-19 outbreak, ${ }^{103}$ Communication from the Commission European Commission Guidelines: Facilitating Air Cargo

99 Council Recommendation (EU) 2020/1475 of 13 October 2020 on a coordinated approach to the restriction of free movement in response to the COVID-19 pandemic [2020] OJ L 337/3.

100 Commission Delegated Regulation (EU) 2020/2115 of 16 December 2020 amending Regulation (EC) No 1008/2008 of the European Parliament and of the Council as regards the temporary extension of exceptional measures to address the consequences of the COVID-19 pandemic with regard to operating licences, [2020], OJ L 426.

101 Regulation (EU) 2020/459 of the European Parliament and of the Council of 30 March 2020 amending Council Regulation (EEC) No 95/93 on common rules for the allocation of slots at Community airports, [2020], OJ L 99.

102 European Commission, Covid-19 Guidelines for border management measures to protect health and ensure the availability of goods and essential services 2020/C 86 I/01 [2020] OJ C 861.

103 Communication from the Commission Guidelines concerning the exercise of the free movement of workers during COVID-19 outbreak [2020], OJ C 102I. 
Operations during COVID-19 outbreak, ${ }^{104}$ Consolidated text: Council Recommendation (EU) 2020/1475 of 13 October 2020 on a coordinated approach to the restriction of free movement in response to the COVID-19 pandemic, ${ }^{105} \mathrm{Eu}$ ropean Commission, Communication from the Commission on the implementation of the Green Lanes under the Guidelines for border management measures to protect health and ensure the availability of goods and essential services, ${ }^{106}$ etc. Their content and more detailed analysis are valuable material for future research and some other paper.

\section{CONCLUDING REMARKS}

On 30 January 2020, due to the global epidemic of a novel coronavirus, the Director General of the World Health Organisation (WHO) declared a Public Health Emergency of International Concern, and on 11 March 2020, WHO declared a global pandemic.

In order to limit the spread of the virus, EU Member States have adopted various measures, some of which have affected the right of European Union citizens to move and reside freely within the territory of the Member States, such as travel bans, entry requirements and various conditions related to border crossing and transit to another country, cross-border travellers required to remain in quarantine, etc., which has led to a considerable number of cancellations and the inability to travel. Health protection before, during and after air travel is imperative on the part of both the passenger and the carrier.

The COVID-19 pandemic took our society by surprise, the foundations of the European Union such as solidarity and freedom of movement have been shaken, and the fundamental rights and trust of citizens have been violated. The aviation industry is recording the biggest losses ever, which inevitably affects the global economy.

As the epidemiological situation worsens, planning and making a trip is becoming more complex so passengers need clear information to minimise risks and costs. Measures to reduce the chance of virus transmission include more frequent clean-

104 Communication from the Commission European Commission Guidelines: Facilitating Air Cargo Operations during COVID-19 outbreak [2020], OJ C 100I.

105 Consolidated text: Council Recommendation (EU) 2020/1475 of 13 October 2020 on a coordinated approach to the restriction of free movement in response to the COVID-19 pandemic [https://eur-lex. europa.eu/legal-content/EN/TXT/?uri=CELEX\%3A02020H1475-20210202].

106 European Commission, Communication from the Commission on the implementation of the Green Lanes under the Guidelines for border management measures to protect health and ensure the availability of goods and essential services, [2020], OJ C 961. 
ing, temperature checks for staff members and passengers, improving ventilation, physical distancing, use of face masks, etc. However, it seems that the provisions to quarantine after travel and the quarantine period had the greatest impact on travel planning or cancellation.

International organisations have adopted a number of rules, recommendations and guidelines for air transport during the COVID-19 pandemic. The highest priority of aviation is safety, and over the past year, various procedures and measures have been established to achieve this goal and thus enable safe travel. On the other hand, regulations on travel restrictions, quarantine, mandatory testing and the like are enacted at national level, which puts additional pressure on passengers and airlines. Although an initiative has been launched at EU level to create joint measures in terms of a coordinated approach to facilitate travel at least within the Schengen Area, this has not produced any desired results so far.

The spread of the pandemic has not only caused problems related to the reduction of available staff both on planes and at airports, but also opened issues related to the vaccination of priority groups like persons working in transport and tourism. Apart from facing a large drop in the number of passengers carried, air carriers also face a number of other difficulties before and during a flight (from collecting various data, disinfection, additional checks on passengers and their health), which puts additional pressure on staff. Although it has been proved that the risk of infectious disease transmission in the aircraft cabin is extremely low, passengers are still reluctant to travel due to uncertain and changing regulations, test costs and the like. In this regard, passengers should be further educated on the safety of air travel. Due to the reduced number of passengers, flights are cancelled, and airlines accumulate losses. The world's most important organisations - WHO, ICAO and the EU EASA, responded to the pandemic by adjusting the existing rules, but in practice this did not lead to an increase in the number of passengers carried. New measures and government assistance in terms of cooperation with the transport and tourism sectors are needed to enable a return of passengers in these new circumstances. What is necessary is better coordination and cooperation not only between the states, but also within individual states and between states and carriers. A balanced approach that takes into account verified health and scientific results will contribute most to an increase in the number of trips and the recovery of the transport sector.

Due to the re-emergence of the pandemic in early 2021, as well as the emergence of new virus strains, it is difficult to predict air traffic recovery, and statements coming from the aviation industry are not optimistic either. 
If joint measures and assistance are lacking and if passengers are not able to travel more easily with simpler procedures such as cheaper rapid tests and a unified digital way of data collection, if the vaccine is not easily accessible to everyone, "aviation's recovery from the COVID-19 crisis will be a long-haul flight." 107

\section{REFERENCES}

\section{BOOKS AND ARTICLES}

1. Činčurak Erceg, B.; Vasilj, A., Current Affairs in Passengers Rights Protection in the European Union, International Scientific Conference "EU Law in Context - Adjustment to Membership and Challenges of the Enlargement (ECLIC)“, Vol. 2 (2018), Osijek, 14-15 June 2018, pp. 216-234

2. Drake, S., Delays, cancellations and compensation: Why are air passengers still finding it difficult to enforce their EU rights under Regulation 261/2004?, Maastricht Journal of European and Comparative Law, Vol. 27, No. 2, 2020, pp. 230-249

3. Fox, S. J.; Martin-Domingo, L., EU Air Passengers' Rights Past, Present, and Future: In an Uncertain World (Regulation (EC) 261/2004: Evaluation and Case Study), Journal of Air Law and Commerce Vol. 85, Issue 2, 2020, pp. 271-308

4. Gutiérrez, A.; Miravet, D.; Domènech, A., COVID-19 and urban public transport services: emerging challenges and research agenda, Cities \& Health, 2020, pp. 1-5

5. Lapaš, D., Pravo medunarodnih organizacija, Narodne novine, Zagreb, 2008

6. Okeke, G.; Kokpan, B., Evaluation of the EU Regulation 261/2004 on Rights of Air Passengers in the Event of Delayed and Cancelled Flights, International Review of Law and Jurisprudence, Vol. 3, No. 2, 2021, pp. 209-218

7. Radionov, N., Ćapeta, T., Marin. J., Bulum, B., Kumpan, A., Popović, N., Savić, I., Europsko prometno pravo, Zagreb, Sveučilište u Zagrebu, Pravni fakultet, 2011

8. Stock, P. G., The International Sanitary Convention of 1944, Proceedings of the Royal Society of Medicine, Vol. XXXVIII, Issue 7, 1945, pp. 309-316

9. Vasilj, A., Jačanje pravnog položaja putnika - potreba uskladivanja nacionalnih propisa s medunarodnim konvencijama i propisima Europske unije, Pravni vjesnik, Vol. 27, No. 1, 2011, pp. 25-55

10. Vasilj, A.; Činčurak Erceg, B., Prometno pravo i osiguranje, Sveučilište Josipa Jurja Strossmayera u Osijeku, Pravni fakultet Osijek, Osijek, 2016

\section{EU LAW}

1. Commission Delegated Regulation (EU) 2020/2115 of 16 December 2020 amending Regulation (EC) No 1008/2008 of the European Parliament and of the Council as regards the

107 EUROCONTROL, Aviation's recovery from the COVID-19 crisis will be a long-haul fight, [https:// www.eurocontrol.int/article/aviations-recovery-covid-19-crisis-will-be-long-haul-flight], Accessed 21 February 2021. 
temporary extension of exceptional measures to address the consequences of the COVID-19 pandemic with regard to operating licences, [2020], OJ L 426

2. Commission Notice - Interpretative Guidelines on Regulation (EC) No 261/2004 of the European Parliament and of the Council establishing common rules on compensation and assistance to passengers in the event of denied boarding and of cancellation or long delay of flights and on Council Regulation (EC) No 2027/97 on air carrier liability in the event of accidents as amended by Regulation (EC) No 889/2002 of the European Parliament and of the Council [2016] OJ C 214

3. Commission Notice Interpretative Guidelines on EU passenger rights regulations in the context of the developing situation with Covid-19 C/2020/1830, [2020] OJ C 89I/01

4. Commission Recommendation (EU) 2020/648 of 13 May 2020 on vouchers offered to passengers and travellers as an alternative to reimbursement for cancelled package travel and transport services in the context of the COVID-19 pandemic, C/2020/3125, [2020], OJ L $151 / 10$

5. Communication from the Commission European Commission Guidelines: Facilitating Air Cargo Operations during COVID-19 outbreak [2020], OJ C $100 I$

6. Communication from the Commission Guidelines concerning the exercise of the free movement of workers during COVID-19 outbreak [2020], OJ C 102I

7. Communication from the Commission to the European Parliament, the European Council and the Council on additional COVID-19 response measures, [2020], COM/2020/687 final

8. Consolidated text: Council Recommendation (EU) 2020/1475 of 13 October 2020 on a coordinated approach to the restriction of free movement in response to the COVID-19 pandemic [https://eur-lex.europa.eu/legal-content/EN/TXT/?uri=CELEX\%3A0202 0H1475-20210202]

9. Council Directive 2004/82/EC of 29 April 2004 on the obligation of carriers to communicate passenger data [2004] OJ L 261/24

10. Council Recommendation (EU) 2020/1475 of 13 October 2020 on a coordinated approach to the restriction of free movement in response to the COVID-19 pandemic [2020] OJ L $337 / 3$

11. European Commission, Communication from the Commission on the implementation of the Green Lanes under the Guidelines for border management measures to protect health and ensure the availability of goods and essential services, [2020], OJ C $96 I$

12. European Commission, Covid-19 Guidelines for border management measures to protect health and ensure the availability of goods and essential services 2020/C 86 I/01 [2020] OJ C 861

13. Joint European Roadmap towards lifting COVID-19 containment measures [2020] OJ C $126 / 01$

14. Proposal for a regulation of the European Parliament and of the council amending Regulation (EC) No 261/2004 establishing common rules on compensation and assistance to passengers in the event of denied boarding and of cancellation or long delay of flights and Regulation (EC) No 2027/97 on air carrier liability in respect of the carriage of passengers and their baggage by air, COM (2013) 130 final - 2013/0072 (COD) 
15. Regulation (EC) No 261/2004 of the European Parliament and of the Council of 11 February 2004 establishing common rules on compensation and assistance to passengers in the event of denied boarding and of cancellation or long delay of flights, and repealing Regulation (EEC) No 295/91 [2004], OJ L 46/1

16. Regulation (EU) 2016/399 of the European Parliament and of the Council of 9 March 2016 on a Union Code on the rules governing the movement of persons across borders (Schengen Borders Code) [2016] OJ L 77/1

17. Regulation (EU) 2016/679 of the European Parliament and of the Council of 27 April 2016 on the protection of natural persons with regard to the processing of personal data and on the free movement of such data, and repealing Directive 95/46/EC (General Data Protection Regulation) [2016] OJ L 119/1

18. Regulation (EU) 2020/459 of the European Parliament and of the Council of 30 March 2020 amending Council Regulation (EEC) No 95/93 on common rules for the allocation of slots at Community airports, [2020], OJ L 99

19. LIST OF NATIONAL REGULATIONS AND INTERNATIONAL CONVENTIONS

20. Convention on International Civil Aviation [https:/www.icao.int/publications/Documents/7300_cons.pdf], Accessed 30 January 2021

21. Decision on the adoption of the National Aviation Safety Programme (Odluka o donošenju Nacionalnog programa sigurnosti u zračnom prometu), Official Gazette, No. 141/2015

22. International Health Regulations (2005) (Odluka o objavi Međunarodnih zdravstvenih propisa (2005)), Official Gazette, International Agreements, No. 9/2013

23. Convention on International Civil Aviation (Konvencija o međunarodnom civilnom zrakoplovstvu), Official Gazette, International Agreements, No. 1/1996

24. International Sanitary Convention, League of Nations Treaty Series - LNTS, Vol. 4, No. 112, 1912. p. 28.

\section{EASA, IATA AND ICAO DOCUMENTS, GUIDELINES, STANDARDS}

1. EASA (European Union Aviation Safety Agency), Guidelines transport of cargo in passenger compartment - exemptions under article 71(1) of Regulation 2018/1139 (The Basic Regulation), [https://www.easa.europa.eu/sites/default/files/dfu/Guidelines $\% 20$ for $\% 20$ the $\% 20$ transport\%20of\%20cargo\%20in\%20passenger\%20aircraft_EASA_issue3_final.pdf], Accessed 10 February 2021

2. EASA and ECDC, COVID-19 Aviation Health Safety Protocol Operational guidelines for the management of air passengers and aviation personnel in relation to the COVID-19 pandemic, Issue No. 02, Issue date: 30 June 2020, [https://www.easa.europa.eu/sites/default/files/dfu/EASA-ECDC_COVID-19_Operational\%20guidelines $\% 20$ for $\% 20$ management\%20of\%20passengers_v2.pdf], Accessed 11 February 2021

3. EASA, European Union Aviation Safety Agency Guidelines Transport of Cargo in Passenger Compartment - Exemptions under Article 71(1) of Regulation (EU) 2018/1139 (The Basic Regulation), [https://www.easa.europa.eu/sites/default/files/dfu/Guidelines $\% 20$ for $\% 20$ the $\% 20$ transport $\% 20$ of\%20cargo\%20in\%20passenger\%20aircraft_EASA_Issue-5.pdf], Accessed 17 February 2021 
4. EASA, Guidance on Aircraft Cleaning and Disinfection in relation to the COVID-19 pandemic, [https:/www.easa.europa.eu/sites/default/files/dfu/EASA\%20Guidance\%20on\%20 aircraft\%20cleaning\%20and\%20disinfection-issue\%202.pdf] Accessed 12 February 2021

5. EASA, Guidance on the management of crew members in relation to the COVID-19 pandemic, [https://www.easa.europa.eu/sites/default/files/dfu/EASA-COVID-19_Guidance $\% 20$ on\%20Management\%20of\%20Crew\%20Members_issue\%202.pdf], Accessed 14 February 2021

6. IATA, Guidance for the transport of cargo and mail on aircraft configured for the carriage of passengers Ed 304 May 2020, [https://www.iata.org/contentassets/094560b4bd9844f da520e9058a0fbe2e/guidance-safe-transportation-cargo-passenger-cabin.pdf], Accessed 15 February 2021

7. IATA, IATA Health Safety Standards Checklist for Airline Operators, [https://www.icao.int/ safety/CAPSCA/PublishingImages/Pages/Coronavirus/IATA\%20Health\%20Safety $\% 20$ Standards\%20Checklist\%20for\%20Airline\%20Operators.pdf], Accessed 15 February 2021

8. IATA, Suspected Communicable Disease, Guidelines for cabin crew, [https://www.iata.org/ contentassets/f1163430bba94512a583eb6d6b24aa56/health-guidelines-cabin-crew.pdf], Accessed 7 February 2021

9. ICAO, Addendum No. 1 to the Technical Instructions for the safe transport of dangerous goods by air (2021/2022 Edition), [https://www.icao.int/safety/DangerousGoods/AddendumCorrigendum\%20to\%20the\%20Technical\%20Instructions/Doc\%209284-20212022.AddendumNo1.en.pdf], Accessed 28 February 2021

10. ICAO, Addendum No. 2 to the Technical Instructions for the safe transport of dangerous goods by air (2021/2022 Edition) [https://www.icao.int/safety/DangerousGoods/AddendumCorrigendum $\% 20$ to\%20the\%20Technical\%20Instructions/Doc\%209284-20212022.AddendumNo2.en.pdf], Accessed 28 February 2021

11. ICAO, Guidelines for states concerning the management of communicable disease posing a serious public health risk [https://www.icao.int/safety/aviation-medicine/guidelines/avinfluenza_guidelines.pdf], Accessed 3 February 2021

12. ICAO, International Standards and Recommended Practices, Annex 9 to the Convention on International Civil Aviation, [https://www.ifrc.org/docs/IDRL/Chicago\%20Convention\%20Annex\%209.pdf], Accessed 3 February 2021

\section{WEBSITE REFERENCES}

1. Ang, C., Visual Capitalist, One Year In: Air Travel Plummeted During the COVID-19 Pandemic, [https://www.visualcapitalist.com/air-travel-plummeted-during-covid-19-pandemic/], Accessed 22 March 2021

2. EASA, Airworthiness aspects for transport of cargo in the passenger cabin of Large Aeroplanes, [https://www.easa.europa.eu/newsroom-and-events/news/airworthiness-aspects-transportcargo-passenger-cabin-large-aeroplanes], Accessed 10 February 2021

3. EASA, Cooperation with the International Civil Aviation Organisation (ICAO), [https://www. easa.europa.eu/domains/international-cooperation/cooperation-with-ICAO], Accessed 7 February 2021 
4. EUROCONTROL, Aviation's recovery from the COVID-19 crisis will be a long-haul flight, [https://www.eurocontrol.int/article/aviations-recovery-covid-19-crisis-will-be-long-haulflight], Accessed 21 February 2021

5. EUROCONTROL, EUROCONTROL Five-Year Forecast 2020-2024, Traffic not expected to reach 2019 levels until 2024 at earliest, [https://www.eurocontrol.int/publication/eurocontrol-five-year-forecast-2020-2024], Accessed 20 February 2021

6. European Centre for Disease Prevention and Control, Considerations relating to passenger locator data, entry and exit screening and health declarations in the context of COVID-19 in the EU/EEA and the UK, https://www.ecdc.europa.eu/sites/default/files/documents/ECDCone-page_EntryScreening_Passenger-Locator-and-Health-Declarations.pdf], Accessed 12 February 2021

7. European Centre for Disease Prevention and Control, Disinfection of environments in healthcare and non-healthcare settings potentially contaminated with SARS-CoV-2, [https://www. ecdc.europa.eu/en/publications-data/disinfection-environments-covid-19], [https:/www. ecdc.europa.eu/sites/default/files/documents/Environmental-persistence-of-SARS_CoV_2Accessed 12 February 2021

8. European Commission, A European roadmap to lifting coronavirus containment measures, [https://ec.europa.eu/info/live-work-travel-eu/coronavirus-response/european-roadmaplifting-coronavirus-containment-measures_en], Accessed 11 February 2021

9. Evans A., ICAO and prevention of spread of disease, [https://www.icao.int/SAM/Documents/2009/MEDSEM/AVMED-\%20prevention\%20of\%20spread\%20of\%20disease. pdf], Accessed 6 February 2021.

10. FAA (U.S. Department of Transportation Federal Aviation Administration), Novel Coronavirus (COVID-19) Update, [https://www.faa.gov/news/updates/?newsId=94991], Accessed 17 February 2021

11. Flight Safety Foundation, Pandemic, Non-medical operational safety aspects; Supplemental materials, [https://fightsafety.org/wp-content/uploads/2020/05/COVID-19-Roadmap-V2. pdf], Accessed 20 February 2021

12. Hrvatska kontrola zračne plovidbe, Financijski plan HKZP-a za 2021., [https://www.crocontrol.hr/app/uploads/2021/02/HKZP-FIN-PLN-2021.pdf], Accessed 28 March 2021

13. Hrvatski zavod za javno zdravstvo, Epidemija pneumonijelakutne respiratorne bolesti uzrokovane novim koronavirusom, Kina, [https://www.hzjz.hr/sluzba-epidemiologija-zaraznebolesti/epidemija-pneumonije-povezana-s-novim-koronavirusom-kina/], Accessed 7 February 2021

14. Hrvatski zavod za javno zdravstvo, Pitanja i odgovori o bolesti uzrokovanoj novim koronavirusom COVID-19, [https://www.hzjz.hr/sluzba-epidemiologija-zarazne-bolesti/pitanja-iodgovori-o-novom-koronavirusu-2019-ncov/], Accessed 7 February 2021

15. IATA, Cabin Air Quality, [https://www.iata.org/en/youandiata/travelers/health/cabin-air/], Accessed 2 February 2021

16. IATA, Continued Government Relief Measures Needed to get Airlines through the Winter, [https://www.iata.org/en/pressroom/pr/2020-06-16-01/], Accessed 20 February 2021

17. IATA, IATA Calls for Passenger Face Covering and Crew Masks, [https://www.iata.org/en/ pressroom/pr/2020-05-05-01/], Accessed 12 February 2021 
18. IATA, IATA Updates COVID-19 Financial Impacts - Relief Measures Needed -, [https://www. iata.org/en/pressroom/pr/2020-03-05-01/], Accessed 20 February 2021

19. IATA, Relief measures, [https://www.iata.org/globalassets/iata/programs/covid/relief-measures-update.pdf], Accessed 20 February 2021

20. ICAO, Airworthiness of Aircraft, Repurposing aircraft passenger cabin for transport of cargo, [https://www.icao.int/safety/COVID-19OPS/Pages/Airworthiness.aspx], Accessed 28 February 2021

21. ICAO, Collaborative Arrangement for the Prevention and Management of Public Health Events in Civil Aviation - CAPSCA, [https://www.icao.int/safety/CAPSCA/Pages/About-CAPSCA.aspx], Accessed 6 February 2021

22. ICAO, Effects of Novel Coronavirus (COVID-19) on Civil Aviation: Economic Impact Analysis, [https://www.icao.int/sustainability/Documents/COVID-19/ICAO_Coronavirus_Econ_ Impact.pdf], Accessed 28 March 2021

23. ICAO, ICAO and the United Nations, [https://www.icao.int/about-icao/History/Pages/icaoand-the-united-nations.aspx], Accessed 21 January 2021

24. ICAO, ICAO and WHO Joint Statement on COVID-19, [https://www.icao.int/Security/COVID-19/PublishingImages/Pages/Statements/Joint\%20ICAO-WHO\%20Statement $\% 20$ on\%20COVID-19.pdf], Accessed 7 February 2021

25. ICAO, ICAO health-related documents, [https:/www.icao.int/MID/Documents/2013/capsca-mid3/ICAOHealthRelatedSARPsandguidelines.pdf], Accessed 7 February 2021

26. ICAO, ICAO-WHO publish joint statement on COVID-19, [https://www.icao.int/Newsroom/Pages/ICAO-WHO-publish-joint-statement-on-COVID-19.aspx], Accessed 8 February 2021

27. ICAO, Managing Communicable Disease in Aviation, [https://www.icao.int/safety/aviationmedicine/pages/healthrisks.aspx], Accessed 30 January 2021

28. ICAO, Public Health Passenger Locator Form, [https://www.icao.int/safety/aviation-medicine/guidelines/AvInfluenza_guidelines_app.pdf], ], Accessed 12 February 2021

29. ICAO, Safety transport of COVID-19 vaccines on commercial aircraft, [https://www.icao. int/safety/OPS/OPS-Normal/Pages/Safety-transport-vaccines.aspx], Accessed 28 February 2021

30. Industry High Level Group (IHLG), Aviation Benefits Report 2019, [https://www.icao.int/ sustainability/Documents/AVIATION-BENEFITS-2019-web.pdf], Accessed 20 February 2021

31. Lexology, Coronavirus and cancelled flights: refund or vouchers?, [https://www.lexology.com/ library/detail.aspx?g=e82dc998-9496-4f35-8dd5-d8eeaae3b9da], Accessed 21 February 2021

32. Lufthansa, Medical certificate: Wearing of a medical protective mask, [https://www.lufthansa.com/content/dam/lh/documents/book-and-manage/travel-information/we-care/faqmouth-nose-cover/certificate-mask-exemption-20210125-en.pdf], Accessed 12 February 2021 
33. Morgan, S., Twelve countries demand passenger rights suspension, [https://www.euractiv.com/ section/aviation/news/twelve-countries-demand-passenger-rights-suspension/], Accessed 2 June 2021

34. Steer Davies Gleave, Exploratory study on the application and possible revision of Regulation 261/2004, Final report, 2012, [https://ec.europa.eu/transport/sites/default/files/themes/passengers/studies/doc/2012-07-exploratory-study-on-the-application-and-possible-revisionof-regulation-261-2004.pdf], Accessed 1 February 2021

35. Steer; European Commission, Study on the current level of protection of air passenger rights in the EU, Final report, 2020, [https://op.europa.eu/en/publication-detail/-/publication/ f03df002-335c-11ea-ba6e-01aa75ed71a1], Accessed 1 February 2021

36. Udruženje zračnog prometa HGK, Udruženje zračnog prometa: Nakon pada od 90\%, oporavak moguć tek 2024., [https://hgk.hr/odrzan-sastanak-udruzenja-zracnog-prometa], Accessed 20 February 2021

37. United Nations Treaty Series Online, International Sanitary Convention for Aerial Navigation, 1944, [https://treaties.un.org/Pages/showDetails.aspx?objid=080000028016391a\&cla ng=_en], Accessed 20 March 2021

38. WHO, WHO Director-General's opening remarks at the media briefing on COVID-19 - 11 March 2020, [https://www.who.int/director-general/speeches/detail/who-director-generals-opening-remarks-at-the-media-briefing-on-covid-19---11-march-2020], Accessed 7 February 2021

39. World Economic Forum, Coronavirus and aviation: Why is air cargo grounded when the world needs it most?, [https://www.weforum.org/agenda/2020/04/coronavirus-aviation-why-is-aircargo-grounded-when-the-world-needs-it-most/], Accessed 15 February 2021

40. World Health Organization, Global Health Histories, Origin and development of health cooperation, [https://www.who.int/global_health_histories/background/en/], Accessed 21 January 2021 